\title{
Behavior of the self-compacting mortar with sugarcane bagasse ash in the fresh and hardened state
}

\section{Estudo do comportamento da argamassa autoadensável com cinza do bagaço de cana-de-açúcar no estado fresco e endurecido}

V. C. SANTOS

viniciuscarrijodossantos@gmail.com https://orcid.org/0000-0002-7501-4998

R. D. VANDERLEI a

rdvanderlei@uem.br https://orcid.org/0000-0001-5676-6951

K. K. MORAES a katherinekaneda@hotmail.com https://orcid.org/0000-0003-4461-850X

E. T. D. F. ROSINA

eti tayna@hotmail.com https://orcid.org/0000-0003-4796-9284

G. M. BALBINO

guilhermebalbino1@live.com https://orcid.org/0000-0001-6394-3805

\begin{abstract}
Self-compacting concrete (SCC) is a material with high workability and moderate viscosity when compared to conventional concrete. Due to its advantages, the SCC has been investigated in the last decades and the research studies the use of new components in its structure and the search for the improvement of its performance, both in the fluid and in the hardened state. The goal of this study was to evaluate the behavior of self-compacting mortars with limestone filler and with the addition of sugarcane bagasse ash (SBA) partially replacing the small aggregate. To reach this goal, initially, a rate of replacement of natural sand by SBA was set. Afterwards, slump-flow and funnel-V tests were carried out in order to check the behavior of the mortars in the fresh state. After checking the behavior of the mortars in their fresh state, the different mix proportions that achieved the best aspects of fluidity and viscosity was selected, and, for self-compacting mortars, specimens were molded to determine tensile strength at 28 days, and compressive strength at 7 and 28 days. The experimental analyses demonstrated an increase in viscosity and reduction in fluidity with increasing content of limestone filler, facilitating the obtaining of self-compacting mortars. Regarding the performance of the material in the hardened state, the mortars showed a slight increase in tensile and compressive strength due to the filler effect of fines. It was possible to replace $40 \%$ of the small aggregate with SBA.
\end{abstract}

Keywords: self-compacting mortar, sugarcane bagasse ash, limestone.

\section{Resumo}

O concreto autoadensável (CAA) é um material que apresenta alta trabalhabilidade e moderada viscosidade quando comparado ao concreto convencional. Em função de suas vantagens, nas últimas décadas, o CAA vem sendo investigado e as pesquisas abordam a utilização de novos componentes em sua estrutura e a busca pela melhoria de seu desempenho, tanto no estado fluido quanto no endurecido. Este estudo teve como objetivo avaliar o comportamento de argamassas autoadensáveis com fíler calcário e com a adição de cinza do bagaço de cana-de-açúcar (CBCA) em substituição parcial ao agregado miúdo. Para atingir este objetivo, inicialmente, uma taxa de substituição de areia natural por CBCA foi definida. Na sequência, foram realizados ensaios de espalhamento e funil-V com o intuito de verificar o comportamento das argamassas no estado fresco. Após a verificação do comportamento das argamassas em seu estado fresco, a série de traços que obteve os melhores aspectos de fluidez e viscosidade foi selecionada, e, para as argamassas autoadensáveis foram moldados corpos-de-prova para determinação da resistência à tração aos 28 dias, e resistência à compressão aos 7 e 28 dias. As análises experimentais demonstraram um aumento de viscosidade e redução da fluidez à medida em que se aumentava o teor de fíler calcário, facilitando a obtenção de argamassas autoadensáveis. Com relação ao desempenho do material no estado endurecido, as argamassas apresentaram leve incremento de resistência à tração e à compressão, devido ao efeito fíler dos finos. Foi possível substituir $40 \%$ do agregado miúdo por CBCA.

Palavras-chave: argamassa autoadensável, cinza do bagaço de cana-de-açúcar, fíler calcário. 


\section{Introduction}

Concrete is the most widely used construction material in the world, but with all the dynamics and innovations in engineering projects, it was necessary to carry out in-depth studies on this component of civil construction, developing new types of concrete that go beyond conventional concrete such as high-performance concrete, fiber reinforced concrete, concrete with high content of pozzolanic additives, apparent concrete, white, colored, sustainable and selfsupporting concretes, among others [1].

The emergence of the material that would later be called self-compacting concrete was justified by [2], due to the low ability that the workers had to perform a satisfactory concreting. The demand for ever more durable concrete structures also encouraged the development of a material that was spread by the action of its own weight, material that would reduce the need for human intervention, resulting in better concreted parts.

Self-compacting concrete (SCC) is a material that does not require vibration during the launching and densification phases; however in order to be considered self-compacting, it must meet certain requirements: workable, no segregation, no exudation, or blockages in densely reinforced structural elements [3].

In order to effectively determine the proportion of constituent materials of self-compacting concrete, it is important to pay special attention to the mortar dosing, since the SCC is composed primarily of mortar and large aggregate. For this reason, it is more convenient to make the adjustments and tests in the mortar phase, which will later compose the SCC.

When the concrete is deformable, the cement paste with high viscosity prevents the increase of internal stress on the large aggregate particles. The high deformability of the self-compacting concrete can be obtained only by the use of superplasticizer additive, without the need to change the water/cement ratio of the mortar [2].

The achievement of good results in self-compacting concretes is possible through studies on the dosing of mortar. By studying the mortar, it is possible to determine if the material has too much fluidity, low viscosity, segregation and exudation. The mortar dosing step is very important, considering that in this phase the proportions of materials must be constituted in such a way that the SCC does not lose workability.

Another important factor in the production of concrete is the high consumption of aggregates, among them, sand, a natural resource very exploited and used by civil construction as a small aggregate.
The extraction of alluvial materials from rivers has been strongly condemned by several sectors of society, this is mainly due to the potential imbalance that this activity can cause in fluvial dynamics, as an immediate consequence of this activity occurs the redefinition of the limits of the channel, either by removal or addition of materials, which in turn can promote changes in sediment flow and sediment transport patterns [4].

In the sugar and alcohol industry, one of the by-products generated from the production of sugar, alcohol and other products is sugarcane bagasse (SB). From the energy cogeneration in the sugar-alcohol plants, where the SB is used as fuel for the boilers in the generation of energy, a residue called Sugarcane Bagasse Ash (SBA) is originated, which until now has no economic value for the industry.

Given the environmental imbalances that sand extraction can cause, the use of renewable and alternative materials may be a solution. Therefore, one of the proposals of this study is the use of SBA, material from renewable sources, replacing partially the small aggregate (sand), in the dosage of self-compacting mortars. In Brazil, the sugar and alcohol industry consists of a very wellstructured segment, in terms of its production chain. The country is the world's largest producer of sugarcane, followed by India and China. For the 2016/2017 growing season, the country expects to produce and to destine to the industry 684.77 million tons of sugarcane $(3.27 \%$ more than the previous harvest), distributed in an area of about 8.97 million hectares in all producing states. The largest Brazilian State in sugarcane production is São Paulo $\left(52.30 \%\right.$ of the planted area), and Paraná ranks $4^{\text {th }}$ in the ranking of producing states, with $7.00 \%$ of the Brazilian area planted [5].

According to FIESP/CIESP [6] data, 260 kilograms SB are generated for each ton of processed sugarcane, of these 260 kilograms of BCA destined for burning, 6.20 kilograms of SBA are generated. Therefore, when applying these values to the projection of the 2016/2017 sugarcane harvest in Brazil, considering that all the expected production is destined to the industry, approximately 178 million tons of BCA would be generated, if all this bagasse was destined for burning approximately 4.24 million tons of SBA would be generated in the crop in question.

The goal of this study is to develop mortar with self-compacting characteristics, partially replacing the small aggregate with sugarcane bagasse ash (SBA) and using the limestone filler as fine to control the viscosity. In this way, it was evaluated the behavior of its mechanical properties (compressive and tensile strength).

\section{Table 1}

\section{Characterization of CP V ARI Ultra cement [8]}

\begin{tabular}{cc} 
Control item & Unit \\
\hline Initial setting time & hours \\
Final setting time & hours \\
Specific gravity & $\mathrm{g} / \mathrm{cm}^{3}$ \\
8.90 & $\mathrm{MPa}$ \\
Compressive strength at the end of day 1 & $\mathrm{MPa}$ \\
Compressive strength at 3 days & $\mathrm{MPa}$ \\
Compressive strength at 7 days & $\mathrm{MPa}$ \\
Compressive strength at 28 days & 3.20 \\
\hline
\end{tabular}


Table 2

Sand characterization

\begin{tabular}{ccc}
\hline Characteristics & Unit & Values \\
\hline Specific mass $\left(\gamma_{\mathrm{s}}\right)$ & $\mathrm{kg} / \mathrm{dm}^{3}$ & 2.65 \\
Aggregate absorption $(A B S)$ & $\%$ & - \\
Loose unit weight & $\mathrm{kg} / \mathrm{dm}^{3}$ & 1.52 \\
Compacted unit weight & $\mathrm{kg} / \mathrm{dm}^{3}$ & 1.63 \\
Maximum characteristic diameter $\left(\phi_{\text {max }}\right)$ & $\mathrm{mm}$ & 1.20 \\
Fineness module & $\%$ & 2.84 \\
\hline
\end{tabular}

\section{Material and experimental program}

The experimental program was divided into 4 phases and was developed at the Construction Materials Laboratory, State University of Maringá (UEM). The steps performed in the experimental program are presented below:

In sections 2.1 to 2.5 , each step of the experimental program is presented in detail.

I Characterization of materials - Phase 1;

II Study of the composition of the small aggregate - Phase 2;

III Determination of the optimal proportion of the small aggregate - Phase 3;

IV Self-compacting mortar dosage - Phase 4;

$\checkmark$ Evaluation of the mortar in the hardened state - Phase 5.

\subsection{Material}

The constituent materials in the self-compacting mortar were: Cement; water; sand (medium and fine particle size); Sugarcane bagasse ash (SBA); Calcitic Limestone Filler, and; superplasticizer additive.

The cement used for dosing the mortar was the CPV ARI RS, called Portland cement of high initial strength and resistant to sulfates provided by Votorantim Cimento LTDA. For the determination of the characteristics of the material, the cement characterization was carried out according to NBR 5733: 1991 [7]. The results of the characterization provided by the manufacturer are listed in table 1. According to NBR 5733: 1991 [7], which deals with Portland cement of high initial strength, the binder used in the research meets the requirements of high initial strength obtained by milling Portland clinker, and consists mainly of hydraulic calcium silicates to which the amount of one or more forms of calcium sulfate is added during the operation.

The sand used is of quartz origin from the region of Maringá, State of Paraná. The particle size composition of the sand was based on the NBR NM 248: 2003 [9], and for the classification of this aggre-

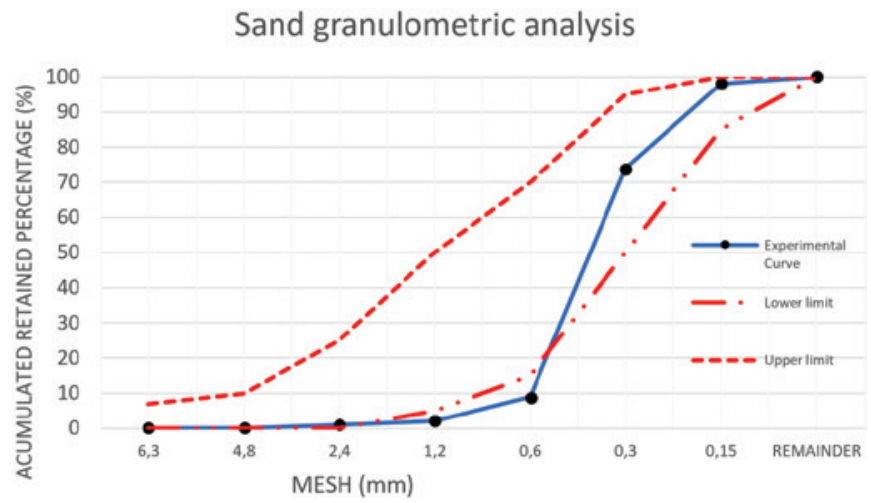

Figure 1

Particle size distribution of the sand used according to NBR 7211:2009

gate, it was used NBR 7211: 2009 [10]. NBR NM 30: 2001 [11] was also used to determine the water absorption of the small aggregate. NBR NM 52: 2002 [12] was applied to determine the specific gravity and apparent specific gravity of the small aggregate. The NBR NM 45: 2006 was used to determine the unit weight and void volume of the small aggregate [13]. Table 2 presents the results for the sand characterization.

From the results obtained by the particle size classification, the limits of the particle size distribution were plotted, as can be seen in figure 1. The additive used in the research was GLENIUM 51, which is classified as third generation for concrete, the product is liquid and free of chlorides, is generally applied to high performance concretes, where it is aimed to minimize the water/cement ratio and increase the durability of the material. The additive is based on a modified polycarboxylic ether chain, which acts as a dispersant of the cementitious material, providing a high reduction in water consumption and superplastification of the material, increasing the workability of the concrete without changing the bonding time. GLENIUM 51 information can be seen in table 3 .

Table 3

Information on the superplasticizer additive used [14]

\begin{tabular}{|c|c|c|c|c|c|c|c|c|c|c|}
\hline Manufacturer & Name & Function & $\begin{array}{l}\text { Chemical } \\
\text { basis }\end{array}$ & $\begin{array}{c}\text { Solid } \\
\text { content } \\
(\%)\end{array}$ & $\mathrm{pH}$ & $\begin{array}{l}\text { Viscosity } \\
\text { (cps) }\end{array}$ & $\begin{array}{l}\text { Density } \\
\left(\mathrm{g} / \mathrm{cm}^{3}\right)\end{array}$ & Aspect & Solubility & Color \\
\hline BASF S/A & $\begin{array}{l}\text { Glenium } \\
51\end{array}$ & $\begin{array}{c}\text { Third generation } \\
\text { superplasticizer } \\
\text { additive }\end{array}$ & $\begin{array}{c}\text { Polycarboxylic } \\
\text { ether }\end{array}$ & $\begin{array}{l}28.50 \\
31.50\end{array}$ & $5-7$ & $<150$ & & Liquid & $\begin{array}{l}\text { Total in } \\
\text { water }\end{array}$ & $\begin{array}{l}\text { Cloudy } \\
\text { white }\end{array}$ \\
\hline
\end{tabular}




\section{Table 4}

Information on the calcitic limestone used [15]

\begin{tabular}{|c|c|c|c|c|c|}
\hline Manufacturer & Name & Function & Chemical basis & Particle size & Color \\
\hline Cazanga & $\begin{array}{c}\text { Calcitic } \\
\text { Limestone }\end{array}$ & $\begin{array}{l}\text { Applications in the } \\
\text { construction and } \\
\text { animal feed industry }\end{array}$ & $\begin{array}{l}\mathrm{CaO}: \text { minimum of } 51.80 \% \\
\mathrm{MgO} \text { : maximum of } 1 \% \\
\mathrm{Ca} \text { : minimum of } 37 \% \\
\mathrm{Mg} \text { : minimum of } 0.63 \%\end{array}$ & $\begin{array}{l}94 \% \text { passing through } 325 \\
\text { mesh sieve, } 94 \% \text { smaller } \\
\text { than } 45 \mu \mathrm{m}(0.045 \mathrm{~mm})\end{array}$ & White \\
\hline
\end{tabular}

The limestone filler used was of calcitic origin and its characteristics, provided by the manufacturer, are listed in table 4 . The sugarcane bagasse ash, used in this study, was collected at the Santa Terezinha Plant in the district of Iguatemi, near the municipality of Maringá, Northwest region of the State of Paraná. To perform the research, the ash was used in natural condition, having as sole processing the sieving through the $0.595 \mathrm{~mm}$ mesh (\# 30), in order to remove the coarse material and impurities.

As the sugarcane bagasse ash used in this research is the same lot as that used in the researches of Nunes [16], Souto [17] and Nagano [18], the chemical and physical characteristics were taken from the researches of the authors mentioned above. Therefore, this information can be seen in table 5 .

The water used in the experiments came from the supply network of the municipality of Maringá, State of Paraná, which according to the requirements of NBR 15900-1: 2009 [19], is entitled Water for kneading concrete-requirements.

\subsection{Composition of the small aggregate}

In order to determine an optimal composition between the small aggregates and the SBA, a study was performed to optimize the compactness between them. For this study, the NBR norm NM 45: 2006 [13] was used to determine the unit weight in the hardened state, where the test was performed for each of the compositions analyzed and the unit weight in the dry compacted state was determined, in this way, the greater unit mass would represent the best composition among the aggregates.

The assay was performed by varying the percentage of the sand composition and SBA 10 by $10 \%$ until reaching a composition with

\section{Table 5}

Characterization of sugarcane bagasse ash from the Iguatemi Plant $[16,17,18]$

\begin{tabular}{|c|c|c|}
\hline Characteristics & Unit & Values \\
\hline * Degree of uniformity $(U)$ & - & 1.62 \\
\hline$* \mathrm{D}_{10}$ & $\mathrm{~mm}$ & 0.13 \\
\hline${ }^{*} D_{30}$ & $\mathrm{~mm}$ & 0.18 \\
\hline${ }^{*} \mathrm{D}_{80}$ & $\mathrm{~mm}$ & 0.21 \\
\hline$*$ Uniformity & - & $\mathrm{U}<5$ (very uniform) \\
\hline${ }^{*}$ Coefficient of curvature (CC) & - & 1.19 \\
\hline * Particle size distribution & - & Well graduated \\
\hline * Particle size classification & - & Similar to sand \\
\hline$*$ Specific mass & $\mathrm{g} / \mathrm{cm}^{3}$ & 2.64 \\
\hline${ }^{*}$ Moisture content & $\%$ & 0.27 \\
\hline$* *$ Specific area & $\mathrm{m}^{2} / \mathrm{kg}$ & 5,356 \\
\hline $\begin{array}{c}{ }^{* *} \text { Mineralogical } \\
\text { composition }-\mathrm{X} \text { diffraction }\end{array}$ & Quartz $\left(\mathrm{SiO}_{2}\right)$ & Highly crystalline, no amorphous phase \\
\hline ** Total organic matter & $\%$ & 3.55 \\
\hline ** Organic carbon & $\%$ & 1.97 \\
\hline ** Pozzolanic activity & $\mathrm{Mg} \mathrm{CaO} / \mathrm{g}$ & 23 \\
\hline$* * \mathrm{SiO}_{2}$ & - & $\begin{array}{l}\text { High silica content in the form of quartz } \\
\text { attributed to low pozzolanic activity }\end{array}$ \\
\hline$* * * \mathrm{C}$ & & 486 \\
\hline$* * * \mathrm{MO}$ & & 8.85 \\
\hline$* * * \mathrm{CaO}$ & & 1.02 \\
\hline$* * * \mathrm{MgO}$ & & 0.15 \\
\hline$* * * \mathrm{~K}_{2} \mathrm{O}$ & $\mathrm{ma} / \mathrm{ka}$ & 0.37 \\
\hline$* * * \mathrm{P}_{2} \mathrm{O}_{5}$ & $\mathrm{mg} / \mathrm{kg}$ & 0.01 \\
\hline$* * * \mathrm{Fe}$ & & $1,375.65$ \\
\hline$* * * \mathrm{Cu}$ & & 29.73 \\
\hline$* * * \mathrm{Mn}$ & & 70.96 \\
\hline$* * * \mathrm{Zn}$ & & 16.82 \\
\hline
\end{tabular}


equal amounts of the two materials ( $50 \%$ sand and $50 \%$ SBA). The composition with the highest unit mass in the hardened state was the one used in the mortar dosages.

\subsection{Determining the optimal proportion of small aggregate}

In order to define the optimal proportion of small aggregate, three series of mix proportions were developed with a cement/small aggregate ratio of 1: 1, 1:2 and 1: 3 , in mass, respectively. After the mortars were made, the slump-flow and $V$-funnel tests were performed for mortars and the self-compacting parameters $(\mathrm{Gm}$ and $\mathrm{Rm}$ ) were obtained in order to determine the best aggregate ratio (sand + SBA) per cement (ar/c) for the production of mortars with the materials used.

\subsection{Dosage of the self-compacting mortar}

For the development and evaluation of the mortar, the methodology proposed by Okamura and Ouchi [2] was used, in which the properties of the mortar in the fresh state (fluidity and viscosity) were analyzed. Mortars already dosed with the optimal proportion of small aggregate were produced with six proportions of limestone filler in relation to the cement mass $(\mathrm{f} / \mathrm{c}$ of $0,0.10,0.20,0.30,0.40$ and 0.50 ), and for each of the six proportions were varied six dosages of superplasticizer additive (sp/c in $\%$ of $0,0.20,0.40,0.60$, $0.80,1.00)$.

After preparation of the mortar, the mini-cone slump-flow and Vfunnel tests were performed for mortars in order to obtain the $G_{m}$ and $R_{m}$ indices, according to equations 1 and 2 .

$G_{m}=\frac{\left(d_{1} \times d_{2}-d_{0}^{2}\right)}{d_{0}^{2}}$

Where: $G m$ : Relative slump-flow for mortars. $d_{1}$ : first slump-flow diameter obtained with the mini-cone for mortars. $d_{2}$ : second slumpflow diameter obtained with the mini-cone for mortars. $\mathrm{d}_{0}{ }^{2}$ : diameter of the base of the mini-cone for mortars.

$R_{m}=\frac{10}{\text { Tempo de escoamento (seg) }}$

Where: $R_{m}$ is the relative flow velocity for mortars.

Determining the values of $\mathrm{Gm}$ and $\mathrm{Rm}$ of the mortar test and carrying out the tests, the fluidity and viscosity properties of the mortar were evaluated for self-compacting mortars.

High value of $\mathrm{Gm}$ indicates greater deformability of the mortar, and lower value of $\mathrm{Rm}$ indicates higher viscosity. Domone and Jin [20] suggest a value of $\mathrm{Gm} \geq 8$, corresponding to slump-flow diameters $\geq 300 \mathrm{~mm}$; and $\mathrm{Rm}$ from 1 to 5 , corresponding to flow times from $2 \mathrm{~s}$ to $10 \mathrm{~s}$. Takada and tangtemsirikul [21] argue that mortars with $\mathrm{Gm}=5$ and $\mathrm{Rm}=1$ are considered very acceptable for obtaining concretes with self-compacting properties. On the other hand, Edmatsu et al. [22] consider that $\mathrm{Gm}$ values between 3 and 7, corresponding to slump-flow diameters of mortar between $200 \mathrm{~mm}$ and $283 \mathrm{~mm}$, and Rm between 1 and 2, corresponding to flow times of 5 to 10 seconds, are considered satisfactory for mortars to be used in the production of SCC. For Nepomuceno and Oliveira [23], the Gm should vary from 5.30 to 5.90 and the Rm should be between
1.14 and 1.30 , which represents a flow time between 7.70 and 8.80 seconds and a slump-flow between $251 \mathrm{~mm}$ and $262 \mathrm{~mm}$.

\subsection{Evaluation of the mortar in the hardened state}

Compressive strength tests were performed at ages of 7 and 28 days and flexural tensile strength at 28 days. For the mortar mix proportions considered to be self-compacting, 3 specimens were prepared for each age, considering the minimum requirement according to the standard and the limitations of the raw material (SBA) of the same lot for all dosages. For the execution of the test of flexural tensile strength, prismatic molds of size $40 \mathrm{~mm} \times 40$ $\mathrm{mm} \times 160 \mathrm{~mm}$ were used. The determination of axial compression strength was performed using cylindrical specimens molded with $50 \mathrm{~mm}$ in diameter and $100 \mathrm{~mm}$ in height. The specimens were kept in a moist curing process until the test age, in which the bases of the specimens were prepared.

The tests of flexural tensile strength were performed from the procedure specified by NBR 13279 [24]. For the axial compressive strength determination, NBR 5739 [25] was used.

\section{Results and discussions}

\subsection{Properties in the fresh state}

The compositions used to determine the compactness between sand and SBA and the results of the unit mass obtained are shown in figure 2. The highest unit mass found among all the compositions was 1.69 , however, the same value is observed in two proportions, with $70 \%$ medium sand and $30 \%$ SBA and with $60 \%$ medium sand and $40 \%$ SBA. In this way, it was decided to use a higher amount of SBA increasing the use of this residue, so that all the mix proportions of mortar were generated by a proportion of small aggregate composed of $60 \%$ sand and $40 \%$ SBA.

In order to define the optimal aggregate content used in the tests, three small aggregate dosages were analyzed in relation to the cement mass (1: 1, 2: 1 and 3: 1). Table 6 lists the results of the self-compacting properties for the three proportions.

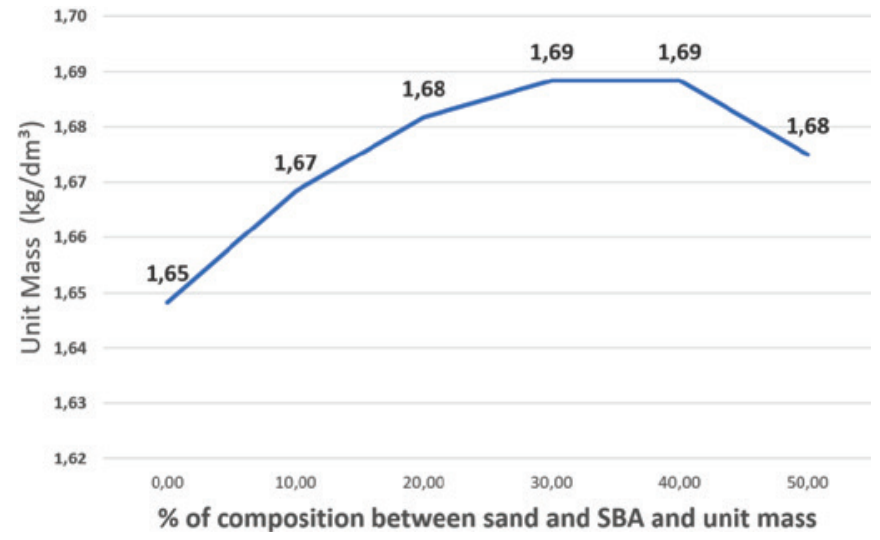

Figure 2

Composition between sand and SBA and unit mass in the hardened state 
Table 6

Results for the fresh state test in the determination of the optimal content of small aggregate

\begin{tabular}{|c|c|c|c|c|c|}
\hline $\begin{array}{c}\text { SP/cement } \\
(\%)\end{array}$ & $\begin{array}{l}\text { D1 slump-flow } \\
(\mathrm{mm})\end{array}$ & $\begin{array}{c}\text { D2 slump-flow } \\
(\mathrm{mm})\end{array}$ & $\begin{array}{c}\text { Flow time } \\
(\mathrm{s})\end{array}$ & Gm & $\mathrm{Rm}$ \\
\hline \multicolumn{6}{|c|}{ Sand : Cement (s/c) mix 1:1 } \\
\hline 0.00 & 165 & 160 & 3.00 & 1.64 & 3.34 \\
\hline 0.20 & 280 & 284 & 1.66 & 6.95 & 6.02 \\
\hline 0.40 & 370 & 365 & 1.84 & 12.50 & 5.43 \\
\hline A partir de 0.60 & Segregação & Segregação & Segregação & Segregação & Segregação \\
\hline $\begin{array}{l}\text { SP/cement } \\
(\%)\end{array}$ & $\begin{array}{l}\text { D1 slump-flow } \\
(\mathrm{mm})\end{array}$ & $\begin{array}{l}\text { D2 slump-flow } \\
(\mathrm{mm})\end{array}$ & $\begin{array}{l}\text { Flow time } \\
\text { (s) }\end{array}$ & Gm & $\mathrm{Rm}$ \\
\hline \multicolumn{6}{|c|}{ Sand : Cement (s/c) mix 2:1 } \\
\hline 0.00 & 100 & 100 & - & - & - \\
\hline 0.20 & 140 & 149 & 5.00 & 1.09 & 2.00 \\
\hline 0.40 & 255 & 258 & 3.25 & 5.58 & 3.08 \\
\hline 0.60 & 360 & 375 & 2.32 & 12.50 & 4.31 \\
\hline 0.80 & 330 & 345 & 1.64 & 10.38 & 6.10 \\
\hline 1.00 & - & - & - & - & - \\
\hline $\begin{array}{c}\text { SP/cement } \\
(\%)\end{array}$ & $\begin{array}{l}\text { D1 slump-flow } \\
(\mathrm{mm})\end{array}$ & $\begin{array}{l}\text { D2 slump-flow } \\
(\mathrm{mm})\end{array}$ & $\begin{array}{l}\text { Flow time } \\
\text { (s) }\end{array}$ & Gm & $\mathrm{Rm}$ \\
\hline \multicolumn{6}{|c|}{ Sand : Cement (s/c) mix 3:1 } \\
\hline 0.00 & - & - & - & - & - \\
\hline 0.20 & 100 & 100 & - & - & - \\
\hline 0.40 & 100 & 100 & - & - & - \\
\hline 0.60 & 100 & 100 & - & - & - \\
\hline 0.80 & 100 & 100 & - & - & - \\
\hline 1.00 & 100 & 100 & - & - & - \\
\hline
\end{tabular}

As can be seen in table 6 , the tests carried out with ar/c ratio of 3 : 1 showed no fluidity signal, thus the flow time values were zero as the material remained cohesive in the V-funnel, the same occurred with the $\mathrm{Rm}$. The mortars produced with a small aggregate ratio of 2: 1 presented adequate fluidity, however, when observing the relative flow index, a high $\mathrm{Rm}$ value was observed due to the low viscosity. The best behavior of the mortars was obtained with ar/c ratio of 2: 1 , in this way, the mortars produced in the study have this dosage.

After determining the proportion of aggregate to be used in the mortar dosages, the mortar tests were performed by varying the fines content, in order to identify the behavior of the material and obtain
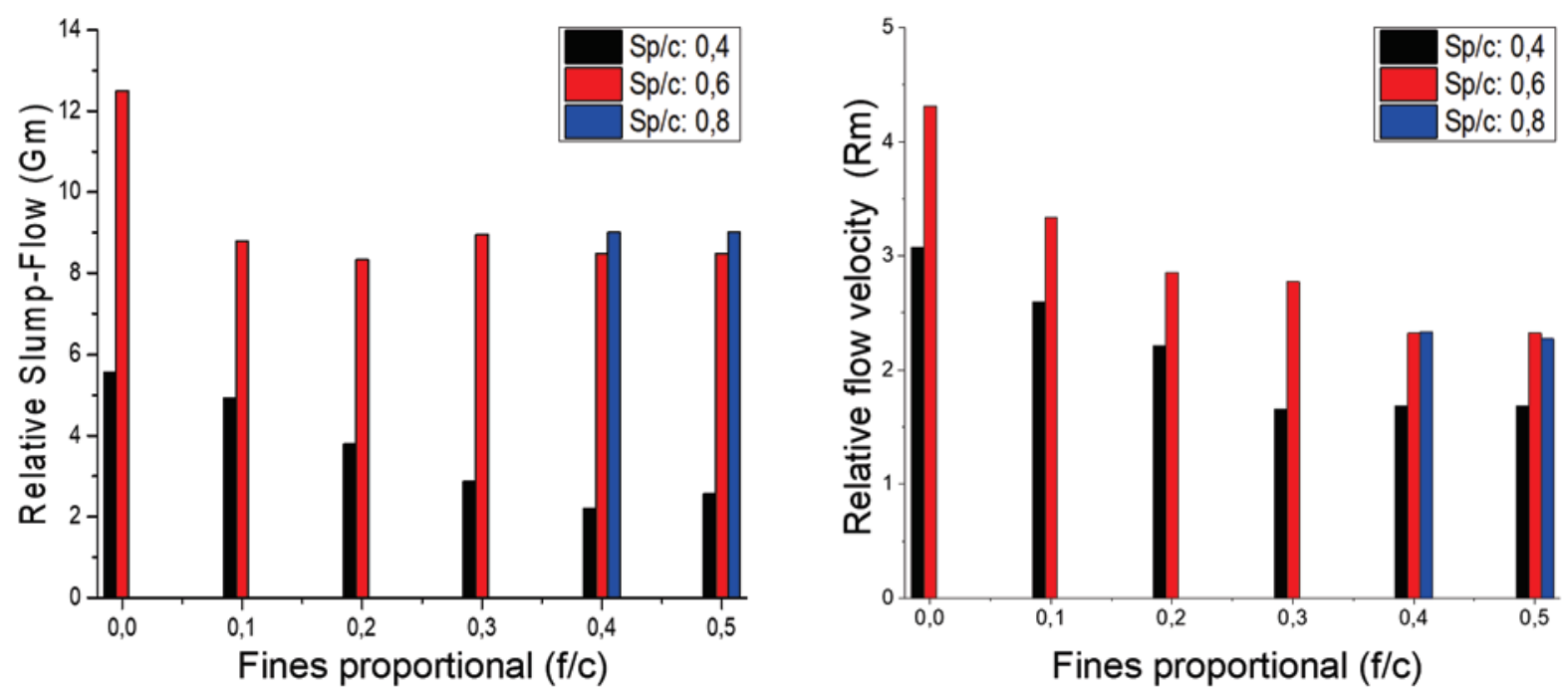

Figure 3

Relative slump-flow area $\left(G_{m}\right)$ and Relative flow velocity $\left(R_{m}\right)$ for self-compacting mortars 
the best relationship between very high fluidity and moderate viscosity required for the mortar be considered self-compacting.

In order to obtain higher viscosity of the mortar with SBA, the addition of fines at six proportions was done, being: $0.00 ; 0.10 ; 0.20 ; 0.30 ; 0.40$ and 0.50 of filler/cement ratio, in addition, for each of the dosages of $\mathrm{f} / \mathrm{c}$ the sp/c ratio was varied in: $0.00 ; 0.20 ; 0.40 ; 0.60 ; 0.80$; and, $1.00 \%$.

For an initial evaluation of its behavior, cone tests were carried out to determine the slump-flow of mortars and v-funnel tests were performed to determine the viscosity of mortars, thus obtaining the indices $\mathrm{Gm}$ and $\mathrm{Rm}$. From the determination of the relative slump-flow index $(\mathrm{Gm})$ and the relative flow index $(\mathrm{Rm})$, it was possible to evaluate the high fluidity and moderate viscosity required by the mortar to be considered self-compacting. The results obtained with the tests for all the mortars are presented in table 7. For the proportions of fines of $0,0.10,0.20$, and 0.30 , the mortars with 0.40 and $0.60 \% \mathrm{sp} / \mathrm{c}$ ratio presented high fluidity and moderate viscosity, however, mortars produced with more than $0.80 \%$ of $\mathrm{sp} / \mathrm{c}$ showed signs of segregation. With the insertion of a higher content of fines $(0.40$ and $0.50 \mathrm{f} / \mathrm{c})$, it was possible to produce Self-Compating Mortars (SCM) with up to $0.80 \% \mathrm{sp} / \mathrm{c}$. All mortars produced with $1.00 \%$ superplasticizer additive, relative to the cement mass (sp/c), presented signs of segregation, with material concentration at the center of the slump-flow and exudation of the mixture at the edges.

The relative slump-flow $\left(G_{m}\right)$ and relative flow velocity $\left(R_{m}\right)$ indices of the self-compacting mortars are shown in figure 3 . The slump-

\section{Table 7}

Results of mini-cone slump-flow ( $\mathrm{Gm}$ ) and mini-V-funnel $(\mathrm{Rm})$ for the traces dosed

\begin{tabular}{|c|c|c|c|c|c|c|}
\hline \multicolumn{7}{|c|}{ Characteristics of the test: small aggregate/cement $=\mathbf{2}$ water/cement $=\mathbf{0 . 5 0}$} \\
\hline Fines/cement & $\begin{array}{c}\text { Sp/cement } \\
(\%)\end{array}$ & $\begin{array}{c}\text { Slump-flow D1 } \\
(\mathrm{mm})\end{array}$ & $\begin{array}{c}\text { Slump-flow D2 } \\
(\mathrm{mm})\end{array}$ & $\begin{array}{l}\text { Flow time } \\
\text { (s) }\end{array}$ & Gm & $\mathrm{Rm}$ \\
\hline \multirow{6}{*}{0.00} & 0.00 & 100 & 100 & - & 0.00 & 0.00 \\
\hline & 0.20 & 140 & 149 & 5.00 & 1.08 & 2.00 \\
\hline & 0.40 & 255 & 258 & 3.25 & 5.57 & 3.07 \\
\hline & 0.60 & 360 & 375 & 2.32 & 12.50 & 4.31 \\
\hline & 0.80 & 330 & 345 & 1.65 & 10.38 & 6.09 \\
\hline & 1.00 & - & - & - & - & - \\
\hline \multirow{6}{*}{0.1} & 0.00 & 102 & 102 & - & 0.04 & - \\
\hline & 0.20 & 110 & 108 & 13.00 & 0.18 & 0.76 \\
\hline & 0.40 & 243 & 244 & 3.85 & 4.93 & 2.59 \\
\hline & 0.60 & 314 & 312 & 3.00 & 8.79 & 3.33 \\
\hline & 0.80 & 333 & 360 & 2.80 & 10.98 & 3.57 \\
\hline & 1.00 & 346 & 340 & 3.20 & 10.76 & 3.12 \\
\hline \multirow{6}{*}{0.2} & 0.00 & 100 & 100 & - & - & - \\
\hline & 0.20 & 110 & 110 & 17.00 & 0.21 & 0.58 \\
\hline & 0.40 & 224 & 214 & 4.53 & 3.79 & 2.21 \\
\hline & 0.60 & 302 & 309 & 3.50 & 8.33 & 2.85 \\
\hline & 0.80 & 318 & 310 & 3.40 & 8.85 & 2.94 \\
\hline & 1.00 & - & - & - & - & - \\
\hline \multirow{6}{*}{0.3} & 0.00 & 100 & 100 & - & - & - \\
\hline & 0.20 & 106 & 100 & 35.00 & 0.06 & 0.28 \\
\hline & 0.40 & 198 & 196 & 6.00 & 2.88 & 1.66 \\
\hline & 0.60 & 317 & 314 & 3.60 & 8.95 & 2.77 \\
\hline & 0.80 & 315 & 313 & 3.20 & 8.86 & 3.12 \\
\hline & 1.00 & - & - & - & - & - \\
\hline \multirow{6}{*}{0.4} & 0.00 & 100 & 100 & - & - & - \\
\hline & 0.20 & 103 & 104 & - & 0.07 & - \\
\hline & 0.40 & 177 & 181 & 5.90 & 2.20 & 1.69 \\
\hline & 0.60 & 310 & 306 & 4.30 & 8.48 & 2.32 \\
\hline & 0.80 & 317 & 316 & 4.30 & 9.01 & 2.32 \\
\hline & 1.00 & 348 & 337 & 4.20 & 10.72 & 2.38 \\
\hline \multirow{6}{*}{0.5} & 0.00 & 100 & 100 & - & - & - \\
\hline & 0.20 & 103 & 104 & - & 0.07 & - \\
\hline & 0.40 & 197 & 181 & 5.90 & 2.56 & 1.69 \\
\hline & 0.60 & 310 & 306 & 4.30 & 8.48 & 2.32 \\
\hline & 0.80 & 317 & 316 & 4.40 & 9.01 & 2.27 \\
\hline & 1.00 & 348 & 337 & 4.40 & 10.72 & 2.27 \\
\hline
\end{tabular}




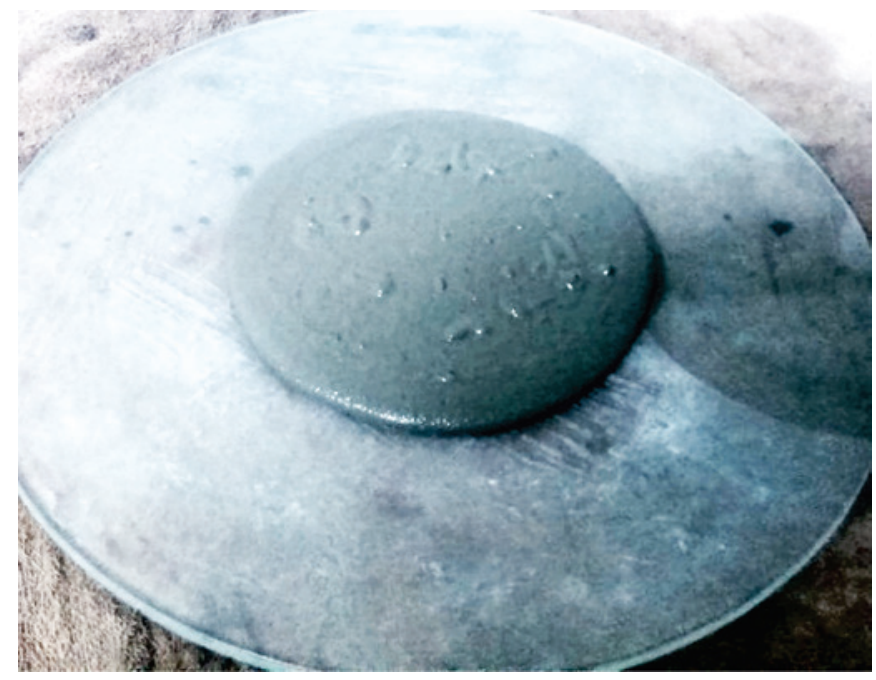

Figure 4

Slump-flow of mortar with 0.30 for $\mathrm{f} / \mathrm{c}$ and $0.40 \%$ for $\mathrm{sp} / \mathrm{c}$

flow $\left(G_{m}\right)$ obtained in mortars considered as self-compacting demonstrate that the higher the use of superplasticizer additive, the greater the relative slump-flow. The impact of the changes in the fines proportions is more evident when using $0.40 \% \mathrm{sp} / \mathrm{c}$ ratio, for the other superplasticizer additive contents, the slumpflow change is smaller.

The relative viscosity $(\mathrm{Rm})$ obtained by means of the $v$-funnel test for mortars aims to demonstrate mainly the viscosity of the analyzed material, in this way, the smaller the value of $\mathrm{Rm}$ the more viscous the mortar. Mortars with $0.40 \% \mathrm{sp} / \mathrm{c}$ ratio showed the highest viscosity, while mortars with 0.60 and $0.80 \% \mathrm{sp} / \mathrm{c}$ ratio did not present major changes. For all the mortars analyzed, the increase in the content of fines gave rise to more viscous mortars, this phenomenon occurs because the limestone filler composes the mortar, filling the voids and consequently increasing the cohesion due to the large surface area of the material. Nevertheless, the maximum effect of the increment in fine mate-

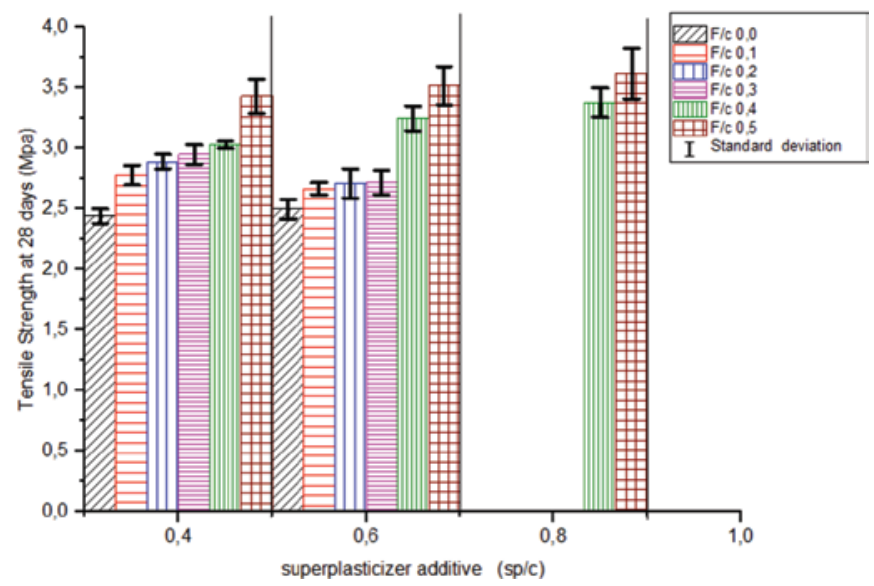

Figure 5

Tensile strength at 28 days for self-compacting mortars rial occurs in the ratios of 0.40 and 0.50 of $\mathrm{f} / \mathrm{c}$, where the viscosity variation is almost null.

Finally, the mortar with the best relationship between fluidity and viscosity and the most capable of producing mix proportions of self-compacting concrete, with the required characteristics, was with $0.40 \% \mathrm{sp} / \mathrm{c}$ ratio and $30 \%$ fine content, relative to the mass of cement. This mix proportions presented average slump-flow of 197.00 millimeters and flow time of 6 seconds, the values for slump-flow and relative flow were respectively 2.88 and 1.66 . Figure 4 illustrates the slump-flow obtained by this mortar. This mortar presented the fluidity necessary to be considered self-compacting and presented very high viscosity, the latter being a vital property when inserting large aggregate in the mortar for the production of self-compacting concrete.

\subsection{Properties in the hardened state}

The results obtained with tensile strength tests from mean values and standard deviations can be visualized in figure 5 .

The self-compacting mortars presented a slight gain of tensile strength by increasing the content of limestone filler. The mortars with higher fines contents presented greater tensile strength, this is because the limestone filler filled empty spaces of the mortar.

The results of the compressive strength tests at 7 days, with their mean values and standard deviations, can be visualized in figure 6. The mortars showed an increase in the compressive strength as they increased the indices of sp/c evaluated, this result was already expected because the a/c ratios used were maintained. On the other hand, the increase in the content of fines resulted in an increase in the compressive strength of the mortars, even though the mortars with $0.50 \mathrm{f} / \mathrm{c}$ presented the best results for the fracture performed at 7 days.

The results obtained with the compressive strength tests at 28 days with their mean values and standard deviations can be visualized in figure 7 . At 28 days, it is possible to notice a general

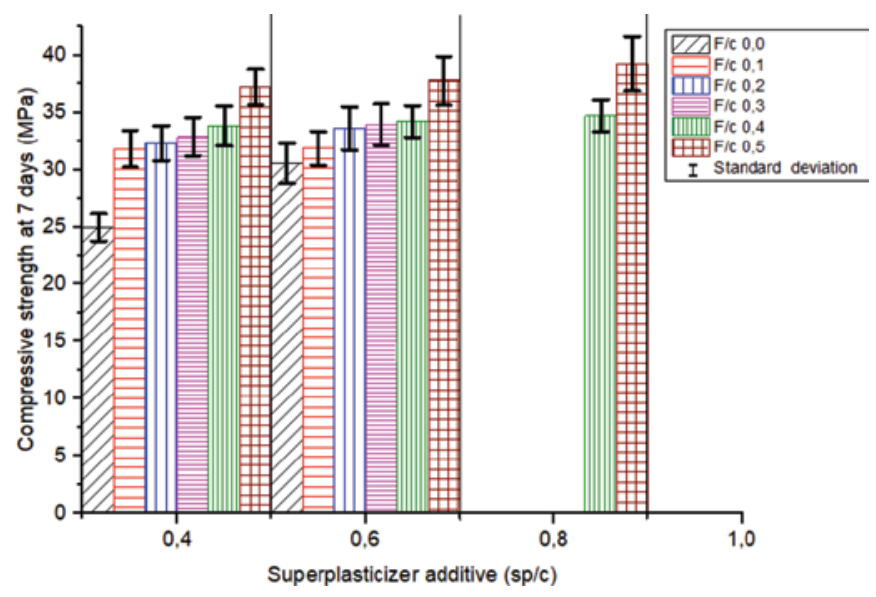

Figure 6

Compressive strength at 7 days

for self-compacting mortars 


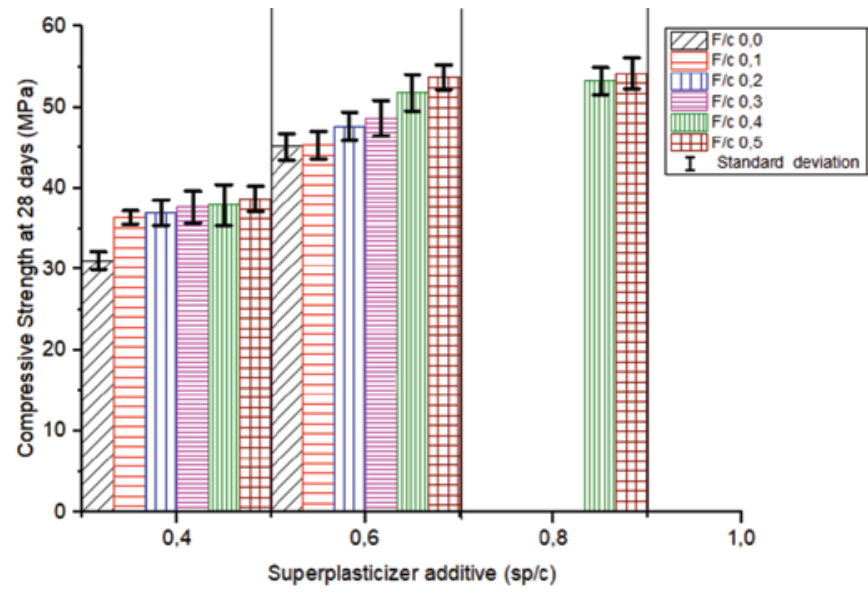

Figure 7

Compressive strength at 28 days

for self-compacting mortars

increase in the compressive strength in the mortars by means of the increase in the content of superplasticizer additive comparing the mix proportions with 0.40 and $0.60 \% \mathrm{sp} / \mathrm{c}$ ratio, this effect is justified by the maintenance of the $\mathrm{a} / \mathrm{c}$ ratio of materials and increase in the use of additive, which when combined, lead to increased hydration of the cement. It is also possible to verify that the increment of calcitic limestone produces an increase in the compressive strength of the mortar because of the greater cohesion and compactness of the materials.

Macedo [26] added sugarcane bagasse ash in mortars and obtained average results of compressive strength at 28 days of 44.70 MPa with ash content of $3 \%$, with $5 \%$ addition of ash, the strength was $48.30 \mathrm{MPa}$, with $8 \%$ addition, the strength was of $46.80 \%$ and of $51.00 \mathrm{MPa}$ with $10 \%$ addition. In the present study, the result of compressive strength obtained from self-compacting mortar with 0.30 of $\mathrm{f} / \mathrm{c}$ and $0.40 \%$ of $\mathrm{sp} / \mathrm{c}$ was $35.40 \mathrm{MPa}$, a result similar to those obtained by Nagano [18], in which self-compacting concrete produced with substitution of $10 \%$ sand by sugarcane bagasse ash presented compressive strength at 28 days of $30.85 \mathrm{MPa}$.

Mollin Filho [27] produced self-compacting concretes with replacement of $10 \%$ sand with sugarcane bagasse ash and reported a tensile strength of $2.56 \mathrm{MPa}$. For the mortar considered self-compacting, in the present study, tensile strength was $2.80 \mathrm{MPa}$ close to that obtained by Mollin Filho [27], considering a greater use of SBA.

\section{Conclusions}

In the fresh state, from the variation in the fine content, it was possible to identify a relationship between increment of calcitic limestone filler and viscosity, while the increase in the dosage of this material provided a reduction in the fluidity. In this way, it can be concluded that the calcitic limestone filler can be used in order to increase the viscosity and to obtain self-compacting mortars. On the other hand, there was a stagnation of this behavior (fluidity and viscosity) in mortars with 0.40 and 0.50 of $\mathrm{f} / \mathrm{c}$ ratio.

The analyzed variations in the superplasticizer additive proved the expected behavior, as the superplasticizer additive dosage in- creases, there is a higher fluidity and lower viscosity in the mortars. Another behavior verified, along with the use of fines, is that using very high fines to obtain high viscosity, requires a proportional increase in the superplasticizer additive used.

In the hardened state, the variations analyzed showed little change in the results. The tensile and compressive strength increases slightly as the use of fines and superplasticizer additive increases. The increased use of fines provides an increase in strength due to the filler effect of the material. The increase in strength, obtained by the increase of the sp/c ratio, is provided by the fact that the same water ratio is used in different superplasticizer additive rates. Another important point to be highlighted is the definition of optimal ranges for obtaining self-compacting mortars with the materials dosed. The mortars that obtained the best aspects of fluidity and viscosity were those produced with a f/c ratio of 0.30 , while the optimum superplasticizer additive dosage range was $0.40-0.60 \%$, in relation to the cement mass.

In this way, it is possible to produce mortars with self-compacting properties with high rate of sugarcane bagasse ash and to obtain increase in viscosity by increasing the dosage of fines. With the results obtained, it is possible to define mix proportions of mortars that will serve as a basis for the production of concretes with self-compacting properties, from the definition of the viscosity and fluidity to be obtained, being possible to define the content of fines more suitable for the SCC production.

Thus, it is feasible to produce concretes with the partial replacement of the small aggregate by sugarcane bagasse ash (SBA), taking into account the conditions under which the experiments of this study were subjected to. Thus, from the results obtained through this study, it was possible to replace $40 \%$ of the small aggregate with $\mathrm{CBCA}$ obtaining a larger unit mass of the composition made between sand and SBA.

\section{Acknowledgements}

To the Graduate Program in Urban Engineering (PEU) and to the Department of Civil Engineering (DEC-UEM), for contributions and assistance during the research.

To the Construction Materials Laboratory for the provision of resources used during the research.

To the Santa Terezinha Plant for donating the SBA.

To BASF do Brasil, which through the engineer Vitor M. Marconi granted the sponsorship of the superplasticizer additive Glenium 51.

\section{References}

[1] ALCOFORADO, L. F. M. Viabilidade econômica do concreto auto-adensável na construção de prédios em Goiânia - GO. Journal on-line Especialize, Goiânia, v. 3, n. 1, p. 1-13, 2013.

[2] OKAMURA, H.; OUCHI, M. Self-compacting concrete. Journal of Advanced Concrete Technology, Tokyo, vol. 1, n. 1, p. 5-15, abr. 2003.

[3] ALCANTARA, M. A. M.; SANTOS, B. V. Concreto auto-adensável com cinzas de bagaço de cana como finos: Reologia do concreto fresco e comportamento no estado endurecido. Eletronic Journal of Civil Engineering, V. 5, N. 1, p. 17-35, 2012. 
[4] OLIVEIRA, F. L; MELLO, E. F. A mineração de areia e os impactos ambientais na bacia do rio São João, RJ. Brazilian Journal of Geosciences, Rio de Janeiro, V. $37,2^{\circ}$ ed., p 374-389, 2007.

[5] CONAB - COMPANHIA NACIONAL DE ABASTECIMENTO. Acompanhamento de safra brasileira: cana-de-açúcar, segundo levantamento, agosto/2016 - Companhia Nacional de Abastecimento. - Brasília: CONAB 2016.

[6] FIESP/CIESP - FEDERAÇÃO DA INDÚSTRIAS DO ESTADO DE SÃO PAULO/ CENTRO DAS INDÚSTRIAS DO ESTADO DE SÃO PAULO Ampliação da oferta de energia através da biomassa. São Paulo: 2001.

[7] ASSOCIAÇÃO BRASILEIRA DE NORMAS TÉCNICAS. ABNT NBR 5733. Cimento Portland de alta resistência inicial. Rio de Janeiro, 1991

[8] OKAMURA, H.; OUCHI, M. Self-compacting concrete. Journal of Advanced Concrete Technology, Tokyo, vol. 1, n. 1, p. 5-15, abr. 2003.

[9] VOTORANTIM. Catálogo de cimentos 2016. Available in: <http://www.mapadaobra.com.br/produtos/cimento/linha>. Access in: November 13, 2015.

[10] ASSOCIAÇÃO BRASILEIRA DE NORMAS TÉCNICAS. ABNT NBR NM 248. Agregados - Determinação da composição granulométrica. Rio de Janeiro, 2003.

[11] ASSOCIAÇÃO BRASILEIRA DE NORMAS TÉCNICAS. ABNT NBR NM 30. Agregado miúdo - Determinação da absorção de água. Rio de Janeiro, 2001.

[12] ASSOCIAÇÃO BRASILEIRA DE NORMAS TÉCNICAS. ABNT NBR NM 52. Agregado miúdo - Determinação de massa específica e massa específica aparente. Rio de Janeiro, 2002.

[13] ASSOCIAÇÃO BRASILEIRA DE NORMAS TÉCNICAS. ABNT NBR NM 45. Agregados - Determinação da massa unitária e do volume de vazios. Rio de Janeiro. 2006.

[14] BASF. Ficha técnica de produto: GLENIUM 51 - Aditivo Superplastificante de terceira geração. Available in: < https://www. ntcbrasil.com.br/wp-content/uploads/2014/12/glenium-51-especificacoes-completas.pdf >. Access in: July 12, 2015.

[15] CAZANGA. Calcário Agrícola: características do produto. Available in: < http://www.cazanga.com.br/index.asp?c= paginas\&modulo $=$ conteudo\&url $=80>$. Access in: August 26, 2015.

[16] NUNES, I. H. S. Estudo das características físicas e químicas da cinza do bagaço de cana-de-açúcar para uso na construção. Masters dissertation. State University of Maringá, UEM, Technology Center, Maringá, 2009.

[17] SOUTO, J. M. F. Avaliação do desempenho da cinza do bagaço de cana-de-açúcar na produção de concretos. 2009, 118f. Master dissertation. State University of Maringá, UEM, Technology Center, Maringá, 2010.

[18] NAGANO, M. F. Dosagem do concreto autoadensável utilizando a cinza do bagaço de cana-de-açúcar. 2014, $142 f$. Master dissertation. State University of Maringá, UEM, Techonolgy Center, Maringá, 2014.

[19] ASSOCIAÇÃO BRASILEIRA DE NORMAS TÉCNICAS. ABNT NBR 15900-1. Água para amassamento do concreto. Rio de Janeiro, 2009.
[20] DOMONE, P. L; JIN, J. Properties of mortar for self-compacting concrete. In: FIRST INTERNATIONAL RILEM SYMPOSIUM ON SELF-COMPACTING CONCRETE, p. 109-120, 1999.

[21] TAKADA, K; TANGTEMSIRIKUL, S. Testing of fresh concrete. In: SELF-COMPACTING CONCRETE: STATE-OF-THE-ART REPORT OF RILEM TECHNICAL COMMITTEE 174-SCC. Cachan: RILEM Publications, S.A.R.L., 2000, p. $20-34$

[22] EDMATSU, H; NISHIDA, N; OUCHI, M. A rational mix-design method for self-compacting concrete considering interaction between coarse aggregate and mortar particles. In: FIRST INTERNATIONAL RILEM SYMPOSIUM ON SELF-COMPACTING CONCRETE, 1999, p. 309-320.

[23] NEPOMUCENO, M; OLIVEIRA, L.; LOPES, S. Methodology for mix design of the mortar phase of self-compacting concrete using different mineral additions in binary blends of powders. Construction and Building Materials. v. 26, n.1, p. 317-326, 2012.

[24] ASSOCIAÇÃO BRASILEIRA DE NORMAS TÉCNICAS. ABNT NBR 13279. Argamassa para assentamento e revestimento de paredes e tetos - Determinação da resistência à tração na flexão e à compressão. Rio de Janeiro, 2005.

[25] ASSOCIAÇÃO BRASILEIRA DE NORMAS TÉCNICAS. ABNT NBR 5739. Concreto - Ensaio de compressão de corpos-de prova cilíndricos. Rio de Janeiro, 2007.

[26] MACEDO, P. C. Avaliação do desempenho de argamassas com adição de cinza do bagaço de cana-de-açúcar. 2009. 116 f. Master dissertation. Paulista State University, Ilha Solteira Engineering College, 2009. 